\section{LETTERS TO THE EDITORS}

The Editors do not hold themselves responsible for opinions expressed by their correspondents. No notice is taken of anonymous communications.

\section{A New Rhesus Antibody}

As antibody of a type hitherto undescribed, which discriminates between certain Rhesus genotypes, has been found in the serum of a male patient, H.Br., of blood group $\mathrm{O}$, suffering from a hæmolytic anæmia of uncertain ætiology. He was transfused on numerous occasions with unselected group $\mathrm{O}$ blood and ultimately began to have reactions suggestive of incompatibility. His serum was found to contain an agglutinin which elumped the red cells of all but about 4 per cent of group $\mathrm{O}$ donors. The cells of one group $\mathrm{O}$ Rhesus-negative subject, C.K., were agglutinated down to a dilution of 1 in 640 by serum obtained in April 1944. In May 1944 the titre against cells of the same subject had fallen to 80 and in January 1945 to 20 . Most of the investigation was carried out with the May serum.

The red cells of 662 group $\mathrm{O}$ donors and other subjects, unselected with respect to the Rhesus factor, have been tested with the serum. Twenty-seven, or 4.1 per cent, are unagglutinated or ' $B r$-negative'. Sixty-nine group O $R h$-negatives, partly included in the above 662 subjects, have all been found to be $\mathrm{Br}$-positive, and in addition $5 \mathrm{Br}$-negatives selected from a different panel from the $69 R h$-negatives have been found to be $R h$-positive.

The Rhesus genotypes of eight $B r$-negatives, including H.Br. himself, were determined by Dr. R. Race and the late Dr. G. L. Taylor. Seven, including H.Br., fell into the class including $R h_{2} R h_{2}$ and $R h_{2} r h$, and one was $R h^{\prime \prime} r h$ or $R h^{\prime \prime} R h^{\prime \prime}$. The father and only child of H.Br. were found to be respectively $R h_{2} R h_{2}$ or $R h_{2} r h$, and $R h_{1} R h_{2}$, both $B r$-positive.

Some $B r$-positives are extremely weak reactors with the rather low-titre specimens of serum now in use, and it appears probable that a few of the apparent negatives would react positively with a stronger serum. Nearly all the weak reactors tested for their $R h$ genotype have contained the gene $R h_{2}$ or $R h^{\prime \prime}$. $R h$-negatives are almost invariably among the strongest reactors.

These properties are consistent with those of the antibody $\eta$ predicted by Fisher ${ }^{1}$. $\eta$ should agglutinate the cells of all $R h$ genotypes containing the genes $R h_{1}, R h^{\prime}, R h_{0}$ and $r h$, but not those of genotypes composed exclusively of $R h_{2}, R h^{\prime \prime}, R h_{z}$ and Fisher's hypothetical $R h_{y}$. Thus most of the negatives will belong to the genotype $R h_{2} R h_{2}$, and $R h_{2} R h^{\prime \prime}$ and $R h^{\prime \prime} R h^{\prime \prime}$ will also be unagglutinated. As stated above, eight subjects negative to $B r$ have been tested with the four antibodies in previous use. If $B r$ is the hypothetical antibody $\eta$, then at least 85 per cent of $B r$ negatives should fall in the class containing $R h_{2} R h_{2}$, which constitutes no more than 15 per cent of the population. Of these eight cases, seven in fact fall in this class. None should fall in the group of classes which does not react to anti- $R h_{2}$ or $H$ : none in fact has been found to do so. The proportion of $\eta$ negatives should be 2.9 per cent, which is in fair agreement with the $4 \cdot 1$ per cent found for $B r$, a figure almost certainly including a fow false negatives due to the weakness of the serum.

In order further to test this hypothesis, use was made of a family at present under genetic investiga- tion, where two members are unambiguously $R h_{2} R h_{6}$ and one $R h_{2} r h$. The former are both $B r$-negative and the latter $B r$-positive. These genotypes were formerly serologically indistinguishable.

The genotypes of strong and weak reactors respectively show that the $B r$ reaction is stronger where two $B r$-positive genes are present than where there is only one. In showing this single- and doubledose effect, $\mathrm{Br}$ resembles $S t^{2,3}$, the other antibody known to agglutinate $R h$-negative cells.

There can thus be little doubt that $B r$ is identical with $\eta$, but genetic studies are continuing which should further confirm their identity. The chief practical value of the serum will lie in distinguishing between the genotypes $R h_{2} R h_{2}$ and $R h_{2} r h$, the only common ones not distinguished by formerly known sera. The distinction is especially important in the fathers of erythroblastotic babies, since the $R h_{2} R h_{2}$ men will have a much smaller chance of begetting healthy offspring than will $R h_{2} r h$ men. The discovery of this serum following soon after Race's discovery of the gene $R h_{z}{ }^{3,4}$ emphasizes the value of Fisher's theory as an instrument of prediction.

This work would not have been possible without the help of the late Dr. G. L. Taylor, who carried out most of the genotyping and gave me much very useful advice. Just before his untimely death, he was engaged in testing the serum against known genotypes and he appeared to have reached full agreement with the conclusions here stated. I am indebted for facilities for this work and much valuable assistance to Dr. H. F. Brewer, Prof. R. A. Fisher, Mr. R. Hudson and Dr. R. R. Race. My thanks are also due to Prof. R. V. Christie for the opportunity of investig. ating the patient concerned.

N.E. London Blood Supply Depot,

A. E. Mourant,

1 See Race, Nature, 153, 771 (1944).

2 Race and Taylor, Nature, 152, 300 (1943).

Race, Taylor, Boorman and Dodd, Nature, 152, 563 (1943).

${ }^{4}$ Murray, Race and Taylor, Nature, 155, 112 (1945).

\title{
Anti-Hr Serum of Levine
}

IN 1941, Levine ${ }^{1}$ in New York described a rare type of anti-Rh serum which was called anti-Hr. This antibody was found in the serum of an $R h$. positive mother of an erythroblastotic infant. Un. fortunately, the weakness of the antibody did not allow the genetics of its corresponding red blood cell antigen to be worked out ${ }^{2}$.

In 1943 , a powerful antiserum now called $S t$ was found in England and the genetics of the antigen which it recognized were worked out ${ }^{3,4,5,6}$. Anti- $H r$ and $S t$ sera were alike in that they both reacted with $R h$-negative and with at least the majority of ' $R h_{2}$ ' cells, but here the similarity ended. Wiener, however, has categorically stated that they are the same antibody? ${ }^{2}$ A powerful example of anti- $H r$ serum has now been found and has recently been described by Waller and Levine ${ }^{8}$. From the description it is quite clear that anti-Hr and $S t$ are not the same antibody. Waller and Levine say "in tests with s potent anti- $H r$ serum all the $R h_{1} R h_{2}$ bloods gave negative reactions. About $60 \%$ of $R h_{1}$ bloods of white individuals and almost all coloured individusls tested possessed the $\mathrm{Hr}$ factor." The original St serum and three identical sera in our collection do 